\title{
Pengaruh Dana Pihak Ketiga, Financing to Deposit Ratio dan Non Performing Financing Terhadap Pertumbuhan Aset PT. Bank Pembiayaan Rakyat Syariah Jabal Nur Surabaya
}

*Sonia Marsella Putri, M. Balafif, Anggraeni Rahmasari

Fakultas Ekonomi dan Bisnis Universitas Bhayangkara Surabaya, Indonesia

DOI: 10.46821/ekobis.v1i2.29

\begin{abstract}
ABSTRAK
Penelitian ini bertujuan untuk menganalisis pengaruh Dana Pihak Ketiga, Financing To Deposit Ratio dan Non Performing Financing terhadap Pertumbuhan Aset PT. Bank Pembiayaan Rakyat Syariah Jabal Nur Surabaya. Data yang digunakan adalah data sekunder, yaitu dari laporan keuangan triwulan yang dipublikasikan oleh Otoritas Jasa Keuangan (OJK). Metode analisis yang digunakan dalam penelitian ini adalah menggunakan analisis regresi berganda. Hasil penelitian ini menunjukkan bahwa terdapat pengaruh secara simultan dari variabel Dana Pihak Ketiga, Financing To Deposit Ratio dan Non Performing Financing terhadap Pertumbuhan Aset PT. Bank Pembiayaan Rakyat Syariah Jabal Nur Surabaya. Secara Parsial, variabel Dana Pihak Ketiga dan Non Performing Financing berpengaruh signifikan terhadap Pertumbuhan Aset, sedangkan variabel lain seperti Financing To Deposit Ratio berpengaruh tidak signifikan terhadap Pertumbuhan Aset PT. Bank Pembiayaan Rakyat Syariah Jabal Nur Surabaya. Dan variabel yang dominan adalah Non Performing Financing.
\end{abstract}

Kata kunci : Dana Pihak Ketiga, Financing To Deposit Ratio, Non Performing Financing, Pertumbuhan Aset

\begin{abstract}
This study aims to analyze the influence of Third Party Fund, Financing To Deposit Ratio and Non Performing Financing to Growth of Sharia People's Financing Bank Assets Jabal Nur Surabaya. The data used is secondary data, that is from quarterly financial report published by Otoritas Jasa Keuangan (OJK). The method of analysis used in this study is to use multiple regression analysis. The results of this study indicate that there is a simultaneous influence of Third Party Fund, Financing To Deposit Ratio and Non Performing Financing to Growth of Sharia People's Financing Bank Assets Jabal Nur Surabaya. Partially, Third Party Fund and Non Performing Financing variable has significant influence to Asset Growth, while other variables such as Financing To Deposit Ratio have an insignificant effect on Asset Growth of Sharia People's Financing Bank Assets Jabal Nur Surabaya. And the dominant variable is Non Performing Financing.
\end{abstract}

Keywords: Third Party Fund, Financing To Deposit Ratio, Non Performing Financing, Asset Growth

\section{PENDAHULUAN}

Perkembangan perbankan syariah di Indonesia telah menjadi tolok ukur keberhasilan eksistensi ekonomi syariah. Krisis moneter yang terjadi pada tahun 
1998 telah menenggelamkan bank-bank konvensional dan banyak yang dilikuidasi karena kegagalan sistem bunganya. Sementara perbankan yang menerapkan sistem syariah dapat tetap berdiri dan mampu bertahan. Hal ini dapat dibuktikan dari keberhasilan bank Muamalat Indonesia melewati krisis yang terjadi pada tahun 1998 dengan menunjukkan kinerja yang semakin meningkat dan tidak menerima sama sekali bantuan dari pemerintah bahkan mampu memperoleh laba Rp 300 miliar lebih. Tidak hanya itu, pada saat krisis keuangan global pada tahun 2008, bank syariah kembali membuktikan daya tahannya dari krisis. Bank syariah tetap stabil dan memberikan keuntungan, kenyamanan dan keamanan bagi para pemegang sahamnya, pemegang surat berharga, peminjam dan para penyimpan dana (Statistik Perbankan Syariah, BI: 2011).

Menurut UU no. 21 tahun 2008, perbankan syariah ialah segala sesuatu yang menyangkut bank syariah dan unit usaha syariah, mencangkup kelembagaan, mencangkup kegiatan usaha serta tata cara dan proses didalam melaksanakan kegiatan usahanya. Pada bank syariah tidak mengenal sistem bunga, karena bunga adalah riba dan riba dilarang dalam Islam, sehingga profit yang didapat bersumber dari bagi hasil dengan pelaku usaha yang menggunakan dana dari bank syariah serta investasi dari bank syariah sendiri. Bank syariah merupakan bank yang menjalankan kegiatan usahanya dengan didasarkan pada prinsip syariah, namun tidak menutup kemungkinan bagi nasabah non muslim, karena prinsip yang dipakai dalam perbankan syariah bersifat universal. Dalam jangka panjang, diharapkan bank syariah dapat bermanfaat bagi setiap manusia tanpa memandang suku, agama, ras dan golongan. Bank syariah berdasarkan jenis dan kegiatan usahanya dibedakan menjadi BUS (bank umum syariah), UUS (unit usaha syariah) dan BPRS (bank pembiayaan rakyat syariah).

Sejarah berdirinya bank pembiayaan rakyat syariah (BPRS) yakni berdasarkan UU no. 7 tahun 1992 tentang Perbankan dan Peraturan Pemerintah (PP) no. 72 tahun 1992 tentang Bank berdasarkan Prinsip Bagi Hasil serta UU no. 10 tahun 1998 tentang Perubahan atas UU no. 7 tahun 1992 tentang Perbankan. Untuk melengkapi dan menyempurnakan UU tersebut maka telah diatur secara khusus eksistensi bank syariah di Indonesia yakni UU no. 21 tahun 2008 disebutkan bahwa bank pembiayaan rakyat syariah adalah bank yang melaksanakan kegiatan usaha berdasarkan prinsip syariah yang dalam kegiatannya tidak memberikan jasa dalam lalu lintas pembayaran. Berdirinya bank pembiayaan rakyat syariah di Indonesia didasari oleh tuntutan bermuamalah secara Islam yang merupakan keinginan kuat dari sebagian besar umat Islam di Indonesia, juga sebagai langkah aktif dalam rangka restrukturisasi perekonomian Indonesia yang dituangkan dalam berbagai paket kebijaksanaan keuangan, moneter, perbankan secara umum. Secara khusus adalah mengisi peluang terhadap kebijaksanaan yang membebaskan bank dalam penetapan tingkat suku bunga, yang kemudian dikenal dengan bank tanpa bunga.

Dalam Islam bank tanpa bunga disebut dengan bank tanpa riba yang artinya bank syariah akan memberikan bagi hasil (nisbah) sebagai imbalan jasa atas simpanan nasabahnya. Periode 1992 sampai dengan 1998 terdapat hanya 1 bank umum syariah dan 78 bank pembiayaan rakyat syariah yang telah beroperasi. Pada tahun 2012 hingga tahun 2016 jumlah kantor bank pembiayaan rakyat syariah terus bertambah. Akan tetapi pada tahun 2017 jumlah kantor bank pembiayaan rakyat syariah mengalami kemunduran dari 453 di tahun 2016 
menjadi 441 di tahun 2017. Hal ini disebabkan karena adanya bank pembiayaan rakyat syariah yang bermasalah akibat tidak dikelola dengan prinsip tata kelola yang baik dan terpaksa harus ditutup. Akan tetapi pada tahun 2018 jumlah kantor bank pembiayaan rakyat syariah mengalami peningkatan $3,9 \%$ dari tahun sebelumnya.

Salah satu kantor bank pembiayaan rakyat syariah yang ada di Indonesia yakni Bank Pembiayaan Rakyat Syariah (BPRS) Jabal Nur yang berlokasi di JL. Gayungsari no. 89, Gayungan, Surabaya, Jawa Timur, 60235. Pertumbuhan bank pembiayaan rakyat syariah tidak hanya dapat dilihat dari jumlah bank dan jumlah kantor, akan tetapi juga dapat dilihat dari pertumbuhan aset bank pembiayaan rakyat syariah. Semakin besar asset bank pembiayaan rakyat syariah maka semakin besar pula kesempatannya dalam mencapai tujuan utamanya yakni memperoleh keuntungan. Persentase pertumbuhan aset bank pembiayaan rakyat syariah pada tahun 2012 hingga tahun 2014 mengalami peningkatan dari 10\% menjadi 22,5\%. Sedangkan, pada tahun 2015 dan 2016 aset bank pembiayaan rakyat syariah mengalami penurunan yang cukup signifikan menjadi $-5,44 \%$ dan $5,35 \%$. Hal ini disebabkan oleh kondisi perusahaan yang menurun, penarikan dana secara besar-besaran, kurangnya kepercayaan masyarakat untuk menyimpan dananya pada bank pembiayaan rakyat syariah Jabal Nur Surabaya, dll.

Faktor - faktor yang berpengaruh terhadap pertumbuhan aset antara lain dana pihak ketiga, financing to deposit ratio dan non performing financing. Dana pihak ketiga berpengaruh terhadap pertumbuhan aset karena semakin besar dana pihak ketiga yang dihimpun oleh bank, berarti semakin besar pula kesempatan bank dalam meningkatkan pertumbuhan aset. Kemudian financing to deposit ratio berpengaruh terhadap pertumbuhan aset karena semakin besar pembiayaan yang disalurkan maka semakin besar pula keuntungan yang dihasilkan sehingga pertumbuhan aset akan meningkat. Sedangkan non performing financing berpengaruh terhadap pertumbuhan aset karena merupakan rasio pembiayaan bermasalah. Kondisi ini menunjukkan bahwa bank pembiayaan rakyat syariah akan semakin hati-hati dalam menyalurkan pembiayaan. Semakin kecil nilai non performing financing maka akan semakin besar keuntungan yang dihasilkan sehingga pertumbuhan aset akan meningkat.

Sesuai latar belakang yang telah dibahas diatas, maka dapat dirumuskan beberapa permasalahan dalam penelitian ini yaitu: Apakah Dana Pihak Ketiga, Financing To Deposit Ratio dan Non Performing Financing mempunyai pengaruh secara simultan terhadap Pertumbuhan Aset PT. Bank Pembiayaan Rakyat Syariah Jabal Nur Surabaya? Apakah Dana Pihak Ketiga, Financing To Deposit Ratio dan Non Performing Financing mempunyai pengaruh secara parsial terhadap Pertumbuhan Aset PT. Bank Pembiayaan Rakyat Syariah Jabal Nur Surabaya?.

\section{TINJAUAN PUSTAKA \\ Pengertian Aset}

Menurut Rizal dkk (2012) Aktiva atau Aset adalah kekayaan (sumber daya) yang dimiliki oleh entitas bisnis yang bisa diukur secara jelas menggunakan satuan uang serta sistem pengurutannya berdasar pada seberapa cepat perubahannya dikonversi menjadi satuan uang kas. Kekayaan perusahaan ini bisa berbentuk wujud fisik atau juga non fisik (hak) yang memiliki nilai. Aktiva adalah sumber 
daya yang dimiliki karena terjadinya peristiwa dimasa lalu dan manfaat ekonominya diharapkan diperoleh perusahaan dimasa yang akandatang.

Menurut Arrazy (2015:15) Pertumbuhan aset adalah pertumbuhan total aktiva lancar yang ditambah dengan pertumbuhan total aktiva tidak lancar. Pertumbuhan aset ini dapat didefinisikan sebagai perubahan atau tingkat pertumbuhan tahunan dari total aset. Pertumbuhan aset secara sistematis dapat dirumuskan sebagai berikut:

Assets Growth $(\%)=\frac{\text { Assets }_{t}-\text { Asset }_{t-1}}{\text { Asset }_{t-1}} \times 100 \%$

Keterangan :

$\mathrm{t}=$ Waktu $\mathrm{t}$ (triwulan).

$\mathrm{t}-1=$ Waktu sebelum $\mathrm{t}$ (triwulan sebelum $\mathrm{t}$ ).

\section{Dana Pihak Ketiga}

Menurut Dendawijaya (2009:24), dana pihak ketiga (DPK) adalah dana yang bersumber dari masyarakat, sumber dana terbesar yang paling diandalkan oleh bank. Setelah dana pihak ketiga telah dikumpulkan oleh bank, maka sesuai dengan fungsi intermediary-nya maka bank berkewajiban menyalurkan dana tersebut untuk pembiayaan. Simpanan mempunyai pengaruh yang paling kuat terhadap pembiayaan, hal tersebut karena simpanan merupakan aset yang dimiliki oleh perbankan syariah yang paling besar sehingga dapat mempengaruhi pembiayaan. Dalam hubungan financing (pembiayaan), simpanan akan mempunyai hubungan positif dimana semakin tinggi tingkat simpanan pada bank syariah semakin meningkat pula kemampuan bank dalam melakukan pembiayaan.

Menurut Muhammad (2005) dana pihak ketiga dapat dihitung dengan rumus :

$$
\text { DPK = Giro + Deposito + Tabungan }
$$

\section{Financing to Deposit Ratio}

Menurut Rivai dan Arifin (2010:784) Financing to Deposit Ratio (FDR) adalah perbandingan antara pembiayaan yang diberikan oleh bank dengan dana pihak ketiga yang berhasil dikerahkan oleh bank. Rasio ini dipergunakan untuk mengukur sampai sejauh mana dana pinjaman yang bersumber dari dana pihak ketiga. Tinggi rendahnya rasio ini menunjukkan tingkat likuiditas bank tersebut. Sehingga semakin tinggi angka financing to deposit ratio suatu bank, berarti digambarkan sebagai bank yang kurang likuid dibanding dengan bank yang mempunyai angka rasio lebih kecil. Rumus untuk mencari financing to deposit ratio adalah sebagai berikut:

$$
F D R=\frac{\text { Jumlah Pembiayaan }}{\text { Total Dana Pihak Ketiga }} \times 100 \%
$$

\section{Non Performing Financing}

Menurut Siamat (2005), Non Performing Financing (NPF) merupakan rasio pembiayaan bermasalah di suatu bank. Pembiayaan bermasalah adalah 
pembiayaan yang pembayaran angsuran pokok lewat 90 hari jatuh tempo, pembiayaan yang pembayarannya secara tepat waktu sangat diragukan. Non performing financing secara luas dapat didefinisikan sebagai suatu pembiayaan dimana pembayaran yang dilakukan tersendat-sendat dan tidak mencakup kewajiban minimal yang ditetapkan sampai dengan pembiayaan yang sulit untuk dilunasi.

Menurut Muhammad (2005) rumus untuk mencari non performing financing adalah sebagai berikut :

$$
\mathrm{NPF}=\frac{\text { JumlahPembiayaanBermasalah }}{\text { Jumlah Pembiayaan }} \times 100 \%
$$

\section{METODE PENELITIAN}

Metode yang digunakan dalam penelitian ini adalah metode kuantitatif. Penelitian ini dilakukan untuk menguji bagaimana pengaruh variabel Dana Pihak Ketiga, Financing to Deposit Ratio dan Non Performing Financing berpengaruh terhadap Pertumbuhan Aset pada PT. Bank Pembiayaan Rakyat Syariah Jabal Nur Surabaya serta mengukur seberapa besar pengaruh tersebut apabila ada.

Untuk menjawab pertanyaan penelitian mengenai faktor-faktor apa yang mempengaruhi proporsi aset perbankan syariah dan untuk mendapatkan besaran pengaruh masing- masing faktor tersebut, dibentuk suatu model dengan menggunakan Regresi Linier Berganda dengan pendekatan estimasi kuarat terkecil OLS (ordinary least square). Kemudian untuk pengujiannya dilakukan dengan uji asumsi klasik, koefisien determinasi dan uji hipotesis melalui program eviews 8 .

\section{HASIL ANALISIS DAN PEMBAHASAN}

Hasil pengujian uji asumsi klasik dilakukan terlebih dahulu sebelum dilakukan pengujian terhadap hipotesis penelitian. Pengujian ini dimaksudkan untuk mengetahui apakah model yang diajukan dalam penelitian ini dinyatakan lolos dari penyimpangan asumsi klasik. Uji asumsi klasik meliputi uji normalitas, uji multikolinearitas, uji heteroskedastisitas dan uji autokorelasi. Hasil uji normalitas dapat diperoleh dari nilai probabilitas Jarque Bera yang dapat dilihat dari Tabel (1).

Tabel 1

Hasil Uji Normalitas

\begin{tabular}{cr}
\hline Nilai Jarque-Bera & 1,486697 \\
\hline Probability & 0,475519 \\
\hline
\end{tabular}

Sumber: Output Eviews 8 (Data diolah)

Tabel 2

Uji Multikolinearitas

\begin{tabular}{cccc}
\hline Variable & Coefficient Variance & Uncentered VIF & Centered VIF \\
\hline DPK & $1.39 \mathrm{E}-13$ & 18.70233 & 1.838766 \\
FDR & 0.001204 & 12.76499 & 1.283414 \\
NPF & 0.012063 & 6.110183 & 2.216775 \\
C & 48.33800 & 23.48538 & NA \\
\hline
\end{tabular}

Sumber: Output Eviews 8 (Data diolah) 


\section{Tabel 3}

Hasil Uji Heteroskedastisitas

\begin{tabular}{ll}
\hline Obs*R-squared & 10,09 \\
\hline Prob. Chi-square & 0,34 \\
\hline
\end{tabular}

Sumber: Output Eviews 8 (Data diolah)

Berdasarkan Tabel 1, menunjukkan nilai probabilitas Jarque Bera hitung adalah sebesar 0,475519 atau >0,05. Maka dapat ditarik kesimpulan bahwa datadata dalam penelitian ini berdistribusi normal.

Kemudian untuk uji multikolinearitas dapat diperolehdari nilai VIF (Variance Inflation Factor) yang dapat dilihat dari Tabel 2.

Berdasarkan tabel diatas, dapat dilihat masing-masing antar variabel bebas memiliki nilai VIF < 10. Dengan demikian dapat ditarik kesimpulan bahwa data dalam penelitian ini tidak terjadi masalah multikolinearitas.

Untuk uji heteroskedastisitas dapat dilihat dari nilai probabilitas Obs*Rsquared yang dapat dilihat dari Tabel 3.

Berdasarkan tabel 3. diperoleh nilai probabilitas Obs*Rsquared sebesar 0,3431 atau >0,05. Maka dapat ditarik kesimpulan bahwa data-data yang digunakan dalam penelitian ini tidak terjadi masalah heteroskedastisitas.

Sedangkan untuk uji autokorelasi dapat dilihat dari nilai Durbin Watson. Dasar pengambilan keputusannya dapat dilihat dari nilai du dan dl. Dengan $n=26$ dan $\mathrm{k}=3$ dapat diketahui nilai batas atas dan batas bawah dari nilai DurbinWatson dengan nilai dU adalah 1,65 dan nilai dL adalah 1,14. Dikarenakan nilai D-W adalah 1,8128 berada diantara dU dan (4-dU), atau 1,65 < 1,803 $<2,35$ maka dapat disimpulkan bahwa hasilnya tidak ada autokorelasi.

Hasil uji regresi linear berganda menghasilkan persamaan sebagai berikut:

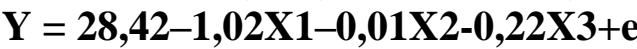

Keterangan:

Y : Pertumbuhan Aset X1 : Dana Pihak Ketiga

$\mathrm{X} 2$ : Financing to DepositRatio

X3 : Non PerformingFinancing

Berdasarkan persamaan regresi diatas dapat dijelaskan sebagai berikut:

1. Koefisien konstanta sebesar 28,42, dengan ini dapat diartikan bahwa pertumbuhan aset (Y) akan bernilai 28,42\% jika, dana pihak ketiga (X1), financing to deposit ratio (X2) dan non performing financing (X3), masingmasing bernilai 0 .

2. Variabel dana pihak ketiga (X1) memiliki nilai koefisien regresi $-1,02$. Hal ini menyatakan bahwa setiap penambahan dana pihak ketiga sebesar $1 \%$ dengan asumsi variabel lain tetap, maka terjadi penurunan pada pertumbuhan aset Bank Pembiayaan Rakyat Syariah dengan nilai -1,02\%. Hubungan berlawanan arah ini dapat dilihat dari koefisien dana pihak ketiga pada fungsi regresi yang bernilainegatif.

3. Variabel financing to deposit ratio (X2) memiliki nilai koefisien regresi sebesar -0,01. Hal ini menyatakan bahwa setiap penambahan financing to deposit ratio sebesar 1\% dengan asumsi variabel lain tetap, maka akan menurunkan pertumbuhan aset Bank Pembiayaan Rakyat Syariah sebesar $0,01 \%$. Hubungan berlawanan arah ini dapat dilihat dari koefisien financing to deposit ratio pada fungsi regresi yang bernilai negatif. 
4. Variabel non performing financing (X3) memiliki nilai koefisien regresi sebesar -0,22. Hal ini menyatakan bahwa setiap penambahan non performing financing sebesar 1\% dengan asumsi variabel lain tetap, maka akan menurunkan pertumbuhan aset Bank Pembiayaan Rakyat Syariah sebesar -0,22\%. Hubungan berlawanan arah ini dapat dilihat dari koefisien non performing financing pada fungsi regresi yang bernilai negatif.

\section{Koefisien Determinasi $\left(\mathbf{R}^{2}\right)$}

Bertujuan untuk mengukur seberapa jauh kemampuan model dapat menerangkan variasi variabel terikat. Nilai koefisien determinasi adalah antara 0 (nol) dan 1 (satu). Nilai koefisien determinasi yang kecil berarti kemampuan variabel-variabel bebas dalam menjelaskan variasi variabel terikat amat terbatas. Nilai yang mendekati satu berarti variabel-variabel bebas memberikan hampir semua informasi yang dibutuhkan untuk memprediksi variasi variabel terikat. Hasil koefisien determinasi dapat dilihat dari besarnya R-square adalah 0,626090 atau $62,6 \%$. Hal ini berarti $62,6 \%$ variabel terikat pertumbuhan aset dapat dijelaskan secara signifikan oleh variasi variabel bebas. Variabel bebas tersebut adalah Dana Pihak Ketiga, Financing to Deposit Ratio dan Non Performing Financing. Sedangkan sisanya sebesar 37,4\% (100\% - 62,6\%) dijelaskan oleh variabel lain diluar model regresi dalam penelitian ini.

Pengujian hipotesis dilakukan dengan uji $\mathrm{F}$ (secara simultan), uji t (secara parsial) dan uji dominan. Berdasarkan Uji F didapatkan nilai probabilitas (prob.) F-statistic sebesar 0,000063 atau $<0,05$ maka $\mathrm{H}_{0}$ ditolak dan $\mathrm{H}_{1}$ diterima.

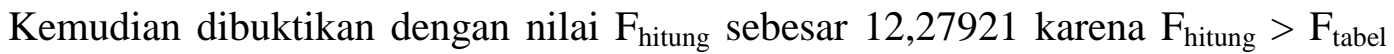
$(12,27921>3,42)$ maka keputusan yang diambil adalah $\mathrm{H}_{0}$ ditolak dan $\mathrm{H}_{1}$ diterima, artinya bahwa secara simultan atau secara bersama- sama dari variabel Dana Pihak Ketiga, Financing to Deposit Ratio dan Non Performing Financing mempunyai pengaruh yang signifikan terhadap Pertumbuhan Aset pada PT. Bank Pembiayaan Rakyat Syariah Jabal Nur Surabaya.

Berdasarkan hasil penelitian, nilai probabilitas (prob.) dari variabel dana pihak ketiga adalah sebesar 0,0125 atau $<0,05$ maka $\mathrm{H}_{0}$ ditolak dan $\mathrm{H}_{1}$ diterima. Kemudian dibuktikan dengan nilai thitung sebesar -2,7194, karena $\mathrm{t}_{\text {hitung }}<\mathrm{t}_{\text {tabel }}(-$ $2,7194<-1,7138)$ maka keputusan yang diambil adalah $\mathrm{H}_{0}$ ditolak dan $\mathrm{H}_{1}$ diterima yang artinya variabel Dana Pihak Ketiga secara parsial berpengaruh negatif dan signifikan terhadap variabel Pertumbuhan Aset pada Bank Pembiayaan Rakyat Syariah Jabal Nur Surabaya.

Nilai probabilitas (prob.) dari variabel financing to deposit ratio adalah sebesar 0,7205 atau > 0,05 maka $\mathrm{H}_{0}$ diterima dan $\mathrm{H}_{1}$ ditolak. Kemudian dibuktikan dengan nilai $t_{\text {hitung }}$ sebesar $-0,3624$, karena $t_{\text {hitung }}>t_{\text {tabel }}(-0,3624>$ 1,7138) maka keputusan yang diambil adalah $\mathrm{H}_{0}$ diterima dan $\mathrm{H}_{1}$ ditolak yang artinya variabel Financing to Deposit Ratio secara parsial berpengaruh negatif dan tidak signifikan terhadap variabel Pertumbuhan Aset pada Bank Pembiayaan Rakyat Syariah Jabal Nur Surabaya.

Nilai probabilitas (prob.) dari variabel non performing financing adalah sebesar 0,0493 atau $<0,05$ maka $\mathrm{H}_{0}$ ditolak dan $\mathrm{H}_{1}$ diterima. Kemudian dibuktikan dengan nilai $t_{\text {hitung }}$ sebesar $-2,0803$, karena $t_{\text {hitung }}<t_{\text {tabel }}(-2,0803<$ 1,7138) maka keputusan yang diambil adalah $\mathrm{H}_{0}$ ditolak dan $\mathrm{H}_{1}$ diterima yang artinya variabel Non Performing Financing secara parsial berpengaruh negatif dan 
signifikan terhadap variabel Pertumbuhan Aset pada Bank Pembiayaan Rakyat Syariah Jabal Nur Surabaya.

Berdasarkan hasil uji dominan dapat diketahui bahwa variabel bebas yang mempunyai koefisien $\beta$ terbesar yang lebih menjauhi (0) nol dan memiliki PValue $<\alpha$ adalah Non Performing Financing dengan nilai koefisien $\beta$ sebesar 0,22 dan nilai P-Value sebesar 0,0493, sehingga dapat disimpulkan bahwa diantara variabel- variabel bebas Dana Pihak Ketiga, Financing to Deposit Ratio dan Non Performing Financing yang paling dominan berpengaruh terhadap variabel terikat Pertumbuhan Aset adalah Non Performing Financing.

\section{SIMPULAN}

Berdasarkan uraian analisis dan pembahasan pada bab sebelumnya, maka dapat disimpulkan sebagai berikut 1) Secara simultan, Dana Pihak Ketiga, Financing to Deposit Ratio dan Non Performing Financing berpengaruh signifikan terhadap Pertumbuhan Aset pada PT. Bank Pembiayaan Rakyat Syariah Jabal Nur Surabaya selama periode triwulan III September 2012-triwulan IV Desember 2018. 2) Secara parsial, Dana Pihak Ketiga dan Non Performing Financing berpengaruh negatif dan signifikan terhadap Pertumbuhan Aset pada PT. Bank Pembiayaan Rakyat Syariah Jabal Nur Surabaya selama periode triwulan III September 2012-triwulan IV Desember 2018. 3) Secara parsial, Financing to Deposit Ratio (FDR) berpengaruh negatif dan tidak signifikan terhadap Pertumbuhan Aset pada PT. Bank Pembiayaan Rakyat Syariah Jabal Nur Surabaya selama periode triwulan III September 2012-triwulan IV Desember 2018. 4) Secara dominan, Non Performing Financing mempunyai pengaruh paling besar terhadap Pertumbuhan Aset pada PT. Bank Pembiayaan Rakyat Syariah Jabal Nur Surabaya selama periode triwulan III September 2012-triwulan IV Desember 2018. Berdasarkan kesimpulan yang telah diuraikan, maka penulis mencoba mengemukakan implikasi yang mungkin bermanfaat diantaranya 1) PT Bank Pembiayaan Rakyat Syariah Jabal Nur Surabaya diharapkan untuk lebih giat lagi dalam menghimpun dana pihak ketiga dengan melakukan berbagai strategi seperti merambah ke sektor jasa dan lain-lain agar bisa meningkatkan pertumbuhan aset. 2) PT Bank Pembiayaan Rakyat Syariah Jabal Nur Surabaya untuk lebih mengembangkan pembiayaan khususnya dengan akad mudharabah. Dengan meningkatkan jumlah pembiayaan diharapkan bisa menurunkan angka financing to deposit ratio agar pendapatan yang dihasilkan lebih maksimal sehingga bisa menambah peningkatan pertumbuhan aset. 3) PT Bank Pembiayaan Rakyat Syariah Jabal Nur Surabaya untuk mengurangi besarnya Non Performing Financing bank dapat mengeluarkan kebijakan antara lain dengan restructuring atau rescheduling terhadap nasabah yang mengalami kesulitan dalam melakukan pelunasan terhadap pembiayaan yang telah diberikan. 4) Penelitian selanjutnya yang berkaitan dengan pertumbuhan aset bank pembiayaan rakyat syariah. disarankan melihat faktor-faktor lain atau lebih mengembangkan variabel bebas yang memungkinkan juga untuk mengembangkan metode analisis selain analisis linier berganda. Variabel yang bisa digunakan CAR (Capital Adequacy Ratio), Return on Asset (ROA) dan Return on Equity (ROE). 


\section{DAFTAR PUSTAKA}

Arrazy, Zakaria. 2015. Pengaruh DPK, FDR, dan NPF terhadap Pertumbuhan Aset Bank Umum Syariah (BUS) di Indonesia tahun 2010-2014. Skripsi, Universitas Islam Negeri Syarif Hidayatullah Jakarta.

Bank Indonesia (BI). Statistik Perbankan Syariah, http://www.bi.go.id.

Dendawijaya, Lukman. 2009. Manajemen Perbankan. Bogor: Ghalia Indonesia.

Muhammad. 2005. Manajemen Dana Bank Syariah. Yogyakarta: Ekonisia.

Otoritas Jasa Keuangan (OJK). Statistik Perbankan Syariah, http://www.ojk.go.id

Rivai, Veithzal dan Zainul Arifin. 2010. Islamic Banking Sebuah Teori, Konsep, dan Aplikasi. Jakarta: Bumi Aksara.

Rizal, Yaya. Martawireja, Aji Erlangga dan Abdurahman, Ahim. 2012. Akuntansi Perbankan Syariah. Jakarta: Salemba Empat.

Siamat, Dahlan. 2005. Manajemen Lembaga Keuangan. "Kebijakan Moneter dan Perbankan”. Edisi 1. Jakarta: Fakultas Ekonomi Universitas Indonesia.

Undang-Undang No. 21 Tahun 2008 Tentang Perbakan Syariah 